\title{
Commentary: Thyrotropin Stimulates Differentiation Not Proliferation of Normal Human Thyrocytes in Culture
}

\author{
Aglaia Kyrilli1,2, Sabine Paternot ${ }^{1}$, Françoise Miot $^{1}$, Bernard Corvilain ${ }^{1,2}$, Gilbert Vassart ${ }^{1}$, \\ Pierre P. Roger ${ }^{1 \dagger}$ and Jacques E. Dumont ${ }^{1 * t}$
}

${ }^{1} / R I B H M$, Université libre de Bruxelles, Brussels, Belgium, ${ }^{2}$ Department of Endocrinology, Erasme University Hospital, Université libre de Bruxelles, Brussels, Belgium

Keywords: TSH, cyclic AMP, human thyrocytes, in vitro proliferation, in vivo proliferation

\section{A commentary on}

OPEN ACCESS

Edited by:

Yuji Nagayama

Nagasaki University, Japan

Reviewed by:

Salvatore Ulisse,

Sapienza Università di Roma, Italy

Cesidio Giuliani,

Università degli Studi "G. d'Annunzio"

Chieti - Pescara, Italy

*Correspondence:

Jacques E. Dumont

jedumont@ulb.ac.be

tThese authors contributed equally to this work.

Specialty section: This article was submitted to Thyroid Endocrinology,

a section of the journal

Frontiers in Endocrinology

Received: 06 July 2017 Accepted: 10 August 2017 Published: 25 August 2017

Citation:

Kyrilli $A$, Paternot $S$, Miot $F$ Corvilain B, Vassart G, Roger PP and Dumont JE (2017) Commentary:

Thyrotropin Stimulates Differentiation Not Proliferation of Normal Human

Thyrocytes in Culture.

Front. Endocrinol. 8:214. doi: 10.3389/fendo.2017.00214
Thyrotropin Stimulates Differentiation Not Proliferation of Normal Human Thyrocytes in Culture

by Morgan SJ, Neumann S, Marcus-Samuels B, Gershengorn MC. Front Endocrinol (2016) 7:168. doi:10.3389/fendo.2016.00168

We want to express our concern about the article "Thyrotropin stimulates differentiation not proliferation of normal human thyrocytes in culture" (1) published recently in this journal. We show that this study draws the wrong conclusions from negative experiments performed in conditions that were previously shown to be inadequate, ignoring fundamental experimental articles on the subject by our group and others (2-11) [see also reviews (12-16)]. The inference that TSH would have no proliferative effect in vivo on human thyrocytes could have negative clinical consequences, as it would negate the fundamental rationale of thyroxine treatment post thyroidectomy for differentiated thyroid cancer or for goiter.

Hereby, we present a compilation of published data showing that TSH, through cAMP, stimulates the proliferation of human thyrocytes in primary culture; we analyze the reasons for Morgan's failure to reach that conclusion; and we summarize the extensive literature on the subject including in vivo and in vitro studies.

We present in Figure 1 the compilation of proliferation results obtained in 35 independent primary cultures used in studies related to previous publications from $1987(6-9,17,18)$. Our protocol complied with ULB ethical rules and was approved by local ethics committee. Cell culture conditions and proliferation measurement by $\mathrm{BrdU}$ or $\left[{ }^{3} \mathrm{H}\right]$ thymidine incorporation are precisely described $(7,8)$. Not one experiment with available results obtained with these proliferation assays was excluded. Although with considerable biological variability, inherent to ex vivo culture of human tissue from surgical origin, we observed that addition of TSH $(0.3 \mathrm{mU} / \mathrm{ml})$, forskolin $(10 \mu \mathrm{M})$, or EGF $(25 \mathrm{ng} / \mathrm{ml}$ ) plus fetal bovine serum (FBS) $10 \%$ to the culture medium significantly increased thyrocyte proliferation rate from median 9.2\% (percentiles 5-95: 1.7-25.2) in control conditions to $25.3 \%$ (3.24-55.2), $18.0 \%$ (3.8-44.15), and $21.3 \%(9.1-49.8)$ in cells stimulated by TSH, forskolin, and EGF + FBS, respectively. TSH stimulation was also perfectly reproduced using highly purified TSH (8). Overall, it was as strong as the maximal cAMP-independent mitogenic stimulation by $\mathrm{EGF}+\mathrm{FBS}$.

There is no doubt that TSH activates thyrocyte proliferation through cAMP in humans in vivo as it does it in experimental animals. It accounts: 


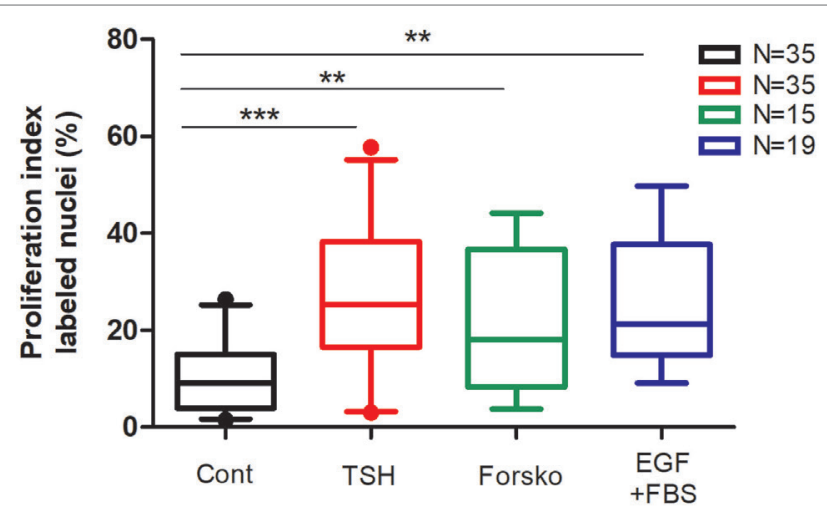

FIGURE 1 | Compilation of human thyrocyte proliferation stimulated by TSH, forskolin, EGF, and fetal bovine serum (FBS) experiments. Human thyroid follicles were prepared by collagenase digestion and seeded in a medium containing Dulbecco's Modified Eagle's Medium, Ham's F-12 nutrient mixture, and MCDB 104 medium (2:1:1, by vol), $1 \mathrm{mM}$ sodium pyruvate, $2 \mathrm{mM}$ glutamine, $5.625 \mu \mathrm{g} / \mathrm{ml}$ insulin, $2.5 \mathrm{mg} / \mathrm{ml}$ human transferrin, $40 \mu \mathrm{g} / \mathrm{ml}$ ascorbic acid, $2.5 \mu \mathrm{g} / \mathrm{ml}$ amphotericin B, $100 \mathrm{U} / \mathrm{ml}$ penicillin, and $100 \mu \mathrm{g} / \mathrm{ml}$ streptomycin (8). To ensure optimal spreading of the follicles $1 \%$ FBS was added for the first $24 \mathrm{~h}$ of culture. The ability of human thyrocytes to proliferate in primary cultures was measured by DNA incorporated BrdU or $\left[{ }^{3} \mathrm{H}\right]$ thymidine (incorporation time $24 \mathrm{~h}$ between days 4 and 5). TSH (0.3 mU/ml), forskolin (Forsko; $10 \mu \mathrm{M})$, and EGF $(25 \mathrm{ng} / \mathrm{ml})+$ FBS 10\% added at day 1 significantly increased the proportion of cell undergoing cell cycle progression. Data (box and whiskers) represent median, quartiles, and 5-95 percentiles. $N=$ number of experiments. Statistical significance was evaluated using an unpaired $t$-test with Welch's correction: ${ }^{* \star} p<0.001,{ }^{\star \star \star} p<0.0001$.

(1) for autonomous adenomas and familial non-immune hyperthyroidism caused by TSHR mutations activating the TSH receptor effect on cAMP $(3,19-22)$;

(2) for the effect on thyroid growth of TSAb in Graves' disease which, through the TSH receptor, activates the cAMP cascade $(5,23,24)$;

(3) for thyroid reduction following suppressive thyroxine therapy (25);

(4) for hyperthyroidism resulting from pituitary hypersecretion of TSH, in the case of TSH secreting adenomas (26). However, in this case TSH activates both the cAMP and IP3-Ca2+ cascades (27).

These conclusions have been validated in transgenic mice in vivo, in which the forced thyrocyte expression of the adenosine A2 receptor (28), activated Gs $\alpha$ (29), or cholera toxin (30), all constitutively activating adenylate cyclase, also leads to hyperthyroidism and goiter. Finally, the mitogenic action of TSH was also demonstrated in xenotransplants of human thyroid tissue in mice $(31,32)$.

With an optimal culture protocol [1\% FBS for follicles seeding, defined medium, presence of IGF1, or insulin $(4,11,18,33)]$ and thyroid material [not goiter, not from old people, not previously frozen, subcultivated, and/or cells exposed to high serum concentrations (34-38)], two doublings of the cell population in 9 days were demonstrated in TSH-stimulated cells in vitro (8).

The possible causes of false negative in in vitro experiments as obtained by Morgan et al. are contradicted by positive results obtained for years in several laboratories and could be explained as follows:

(1) Morgan et al. (1) only used thyrocytes that were initially propagated in the presence of high serum concentration. Both in human thyrocytes (4) and in canine thyroid primary cultures (39), this suffices to irreversibly abolish the mitogenic response to TSH and cAMP as assayed by cell counting and/or DNA synthesis measurements, without impeding the mitogenic response to growth factors or differentiation effects of TSH;

(2) seeding of isolated cells instead of follicles;

(3) inadequate basal culture medium. Dulbecco's Modified Eagle's Medium (DMEM) alone does not support thyrocyte proliferation after serum deprivation;

(4) only use of cell counting which is a good but poorly sensitive measurement in which proliferation can be compensated by cells loss, especially in inadequate culture condition like DMEM medium.

(5) study of "normal" tissue from thyroidectomy performed for thyroid cancer, Graves' disease or multinodular goiter [our 1988 study (8) mostly used thyroid tissue from traffic accident victims]. The proliferative effect of cAMP is a characteristic of normal differentiated thyroid cells which is much decreased in dedifferentiated cells and even more so in cancer cells (40).

Surprisingly, Morgan et al. (1) did not even attempt to reproduce experimental conditions that were successful in other laboratories.

Besides the in vitro arguments, the rationale for treating patients with papillary or follicular carcinoma with suppressive doses of thyroxine is also based on multiple clinical studies with arguments summarized in a review by Biondi et al. (41):

(1) hypothyroidism stimulates neoplastic thyroid cell growth;

(2) patients treated with L-T4 have less recurrence and cancerrelated death than untreated patients;

(3) TSH suppression is an independent factor of slower progression at least in patients with high-risk papillary thyroid cancer.

Even if all these studies are retrospective or prospective but not randomized, they strongly suggest that TSH may stimulate cancer thyroid cell growth. In the last American thyroid Association guidelines (Recommendation 70), TSH suppression below $0.1 \mathrm{mU} / \mathrm{l}$ is recommended in patients with structural incomplete response (strong recommendation, moderate-quality evidence), which is among the strongest recommendations that are made in a field where prospective studies are rare. Questioning this recommendation on the base of in vitro data not obtained by other groups is presumptuous and asking for a double-blind prospective study is unrealistic given the number of patients that should be included and the duration of follow-up to be expected for a slowly evolving disease.

The TSH effect on growth of human thyroid cells should remain the scientific basis of TSH suppression treatment with thyroxine after thyroidectomy for differentiated thyroid cancer and a possibility for the temporary treatment of goiter. 


\section{AUTHOR CONTRIBUTIONS}

$\mathrm{AK}$ and SP have performed experiments and written the manuscript. FM, BC, GV, PR, and JD have performed a thorough literature research and reviewed and commented the manuscript.

\section{REFERENCES}

1. Morgan SJ, Neumann S, Marcus-Samuels B, Gershengorn MC. Thyrotropin stimulates differentiation not proliferation of normal human thyrocytes in culture. Front Endocrinol (2016) 7:168. doi:10.3389/fendo.2016.00168

2. Kimura T, Van Keymeulen A, Golstein J, Fusco A, Dumont JE, Roger PP. Regulation of thyroid cell proliferation by thyrotropin and other factors: a critical evaluation of in vitro models. Endocr Rev (2001) 22:631-56. doi:10.1210/ edrv.22.5.0444

3. Hebrant A, Van SJ, Roger PP, Patey M, Klein M, Bournaud C, et al. Thyroid gene expression in familial nonautoimmune hyperthyroidism shows common characteristics with hyperfunctioning autonomous adenomas. J Clin Endocrinol Metab (2009) 94:2602-9. doi:10.1210/jc.2008-2191

4. Huber GK, Davies TF. Human fetal thyroid cell growth in vitro: system characterization and cytokine inhibition. Endocrinology (1990) 126:869-75. doi:10.1210/endo-126-2-869

5. Huber GK, Safirstein R, Neufeld D, Davies TF. Thyrotropin receptor autoantibodies induce human thyroid cell growth and c-fos activation. J Clin Endocrinol Metab (1991) 72:1142-7. doi:10.1210/jcem-72-5-1142

6. Lamy F, Taton M, Dumont JE, Roger PP. Control of protein synthesis by thyrotropin and epidermal growth factor in human thyrocytes: role of morphological changes. Mol Cell Endocrinol (1990) 73:195-209. doi:10.1016/0303-7207(90)90133-S

7. Paternot S, Dumont JE, Roger PP. Differential utilization of cyclin D1 and cyclin D3 in the distinct mitogenic stimulations of human thyrocytes by growth factors and TSH. Mol Endocrinol (2006) 20:3279-92. doi:10.1210/ me.2005-0515

8. Roger P, Taton M, Van Sande J, Dumont JE. Mitogenic effects of thyrotropin and adenosine 3',5'-monophosphate in differentiated normal human thyroid cells in vitro. JClin Endocrinol Metab (1988) 66:1158-65. doi:10.1210/ jcem-66-6-1158

9. Taton M, Lamy F, Roger PP, Dumont JE. General inhibition by transforming growth factor beta 1 of thyrotropin and cAMP responses in human thyroid cells in primary culture. Mol Cell Endocrinol (1993) 95:13-21. doi:10.1016/0303-7207(93)90024-E

10. Vandeput F, Perpete S, Coulonval K, Lamy F, Dumont JE. Role of the different mitogen-activated protein kinase subfamilies in the stimulation of dog and human thyroid epithelial cell proliferation by cyclic adenosine 5 '-monophosphate and growth factors. Endocrinology (2003) 144:1341-9. doi:10.1210/ en.2001-211316

11. Williams DW, Williams ED, Wynford-Thomas D. Evidence for autocrine production of IGF-1 in human thyroid adenomas. Mol Cell Endocrinol (1989) 61:139-43. doi:10.1016/0303-7207(89)90199-8

12. Dremier S, Coulonval K, Perpete S, Vandeput F, Fortemaison N, Van KA, et al. The role of cyclic AMP and its effect on protein kinase A in the mitogenic action of thyrotropin on the thyroid cell. Ann N Y Acad Sci (2002) 968:106-21. doi:10.1111/j.1749-6632.2002.tb04330.x

13. Dumont JE, Lamy F, Roger P, Maenhaut C. Physiological and pathological regulation of thyroid cell proliferation and differentiation by thyrotropin and other factors. Physiol Rev (1992) 72:667-97.

14. Rivas M, Santisteban P. TSH-activated signaling pathways in thyroid tumorigenesis. Mol Cell Endocrinol (2003) 213:31-45. doi:10.1016/j.mce.2003.10.029

15. Roger PP, van Staveren WC, Coulonval K, Dumont JE, Maenhaut C. Signal transduction in the human thyrocyte and its perversion in thyroid tumors. Mol Cell Endocrinol (2010) 321:3-19. doi:10.1016/j.mce.2009.11.015

16. Dumont JE, Maenhaut C, Christophe D, Roger PP. Thyroid regulatory factors. In: Jameson JL, De Groot LJ, editors. Endocrinology: Adult and Pediatric. (2015) Amsterdam:Elsevier. p. 1297-321.

17. Deleu S, Pirson I, Coulonval K, Drouin A, Taton M, Clermont F, et al. IGF-1 or insulin, and the TSH cyclic AMP cascade separately control dog and

\section{FUNDING}

Fonds Erasme Pour la Recherche Médicale Fonds Docteur JP Naets managed by King Baudouin Foundation. Fond National pour la Recherche Scientifique (FNRS).

human thyroid cell growth and DNA synthesis and complement each other in inducing mitogenesis. Mol Cell Endocrinol (1999) 149:41-51. doi:10.1016/ S0303-7207(99)00005-2

18. Van Keymeulen A, Dumont JE, Roger PP. TSH induces insulin receptors that mediate insulin co-stimulation of growth in normal human thyroid cells. Biochem Biophys Res Commun (2000) 279:202-7. doi:10.1006/ bbrc. 2000.3910

19. Deleu S, Allory Y, Radulescu A, Pirson I, Carrasco N, Corvilain B, et al. Characterization of autonomous thyroid adenoma: metabolism, gene expression, and pathology. Thyroid (2000) 10:131-40. doi:10.1089/ thy.2000.10.131

20. Goffard JC, Jin L, Mircescu H, Van Hummelen P, Ledent C, Dumont JE, et al. Gene expression profile in thyroid of transgenic mice overexpressing the adenosine receptor 2a. Mol Endocrinol (2004) 18:194-213. doi:10.1210/ me.2003-0249

21. Parma J, Duprez L, Van Sande J, Cochaux P, Gervy C, Mockel J, et al. Somatic mutations in the thyrotropin receptor gene cause hyperfunctioning thyroid adenomas. Nature (1993) 365:649-51. doi:10.1038/365649a0

22. Parma J, Van Sande J, Swillens S, Tonacchera M, Dumont J, Vassart G. Somatic mutations causing constitutive activity of the thyrotropin receptor are the major cause of hyperfunctioning thyroid adenomas: identification of additional mutations activating both the cyclic adenosine 3',5'-monophosphate and inositol phosphate-Ca2+ cascades. Mol Endocrinol (1995) 9:725-33.

23. Laurent E, Van Sande J, Ludgate M, Corvilain B, Rocmans P, Dumont JE, et al. Unlike thyrotropin, thyroid-stimulating antibodies do not activate phospholipase C in human thyroid slices. J Clin Invest (1991) 87:1634-42. doi:10.1172/ JCI115178

24. Ludgate ME, Vassart G. The thyrotropin receptor as a model to illustrate receptor and receptor antibody diseases. Baillieres Clin Endocrinol Metab (1995) 9:95-113. doi:10.1016/S0950-351X(95)80851-5

25. Medeiros-Neto G. Multinodular goiter. In: De Groot LJ, Chrousos G, Dungan K, Feingold KR, Grossman A, Hershman JM, Koch C, Korbonits M, McLachlan R, New M, Purnell J, Rebar R, Singer F, Vinik A, editors. Endotext [Internet]. South Dartmouth, MA: MDText.com, Inc. (2000-2016).

26. Beck-Peccoz P, Persani L, Lania A. Thyrotropin-secreting pituitary adenomas. In: De Groot LJ, Chrousos G, Dungan K, Feingold KR, Grossman A, Hershman JM, Koch C, Korbonits M, McLachlan R, New M, Purnell J, Rebar R, Singer F, Vinik A, editors. Endotext [Internet]. South Dartmouth, MA: MDText.com, Inc. (2000-2015).

27. Corvilain B, Laurent E, Lecomte M, Van Sande J, Dumont JE. Role of the cyclic adenosine 3',5'-monophosphate and the phosphatidylinositol-Ca2+ cascades in mediating the effects of thyrotropin and iodide on hormone synthesis and secretion in human thyroid slices. J Clin Endocrinol Metab (1994) 79:152-9. doi: $10.1210 /$ jc. 79.1 .152

28. Ledent C, Dumont JE, Vassart G, Parmentier M. Thyroid expression of an A2 adenosine receptor transgene induces thyroid hyperplasia and hyperthyroidism. EMBO J (1992) 11:537-42.

29. Michiels FM, Caillou B, Talbot M, Dessarps-Freichey F, Maunoury MT Schlumberger M, et al. Oncogenic potential of guanine nucleotide stimulatory factor alpha subunit in thyroid glands of transgenic mice. Proc Natl Acad Sci U S A (1994) 91:10488-92. doi:10.1073/pnas.91.22.10488

30. Zeiger MA, Saji M, Gusev Y, Westra WH, Takiyama Y, Dooley WC, et al. Thyroid-specific expression of cholera toxin Al subunit causes thyroid hyperplasia and hyperthyroidism in transgenic mice. Endocrinology (1997) 138:3133-40. doi:10.1210/endo.138.8.5347

31. Peter HJ, Gerber H, Studer H, Smeds S. Pathogenesis of heterogeneity in human multinodular goiter. A study on growth and function of thyroid tissue transplanted onto nude mice. J Clin Invest (1985) 76:1992-2002. doi:10.1172/ JCI112199 
32. Smeds S, Boeryd B, Jörtsö E, Lennquist S. Normal and stimulated growth of different human thyroid tissues in nude mice. In: Goretzki PE, Röher HD, editors. Growth Regulation of Thyroid Gland and Thyroid Tumors. Basel: Karger (1989). p. 98-108.

33. Huber GK, Fong P, Concepcion ES, Davies TF. Recombinant human thyroid-stimulating hormone: initial bioactivity assessment using human fetal thyroid cells. J Clin Endocrinol Metab (1991) 72:1328-31. doi:10.1210/ jcem-72-6-1328

34. Curcio F, Ambesi-Impiombato FS, Perrella G, Coon HG. Long-term culture and functional characterization of follicular cells from adult normal human thyroids. Proc Natl Acad Sci U S A (1994) 991:9004-8. doi:10.1073/ pnas.91.19.9004

35. Errick JE, Ing KW, Eggo MC, Burrow GN. Growth and differentiation in cultured human thyroid cells: effects of epidermal growth factor and thyrotropin. In Vitro Cell Dev Biol (1986) 22:28-36. doi:10.1007/BF02623438

36. Kraiem Z, Sadeh O, Yose M. Iodide uptake and organification, tri-iodothyronine secretion, cyclic AMP accumulation and cell proliferation in an optimized system of human thyroid follicles cultured in collagen gel suspended in serum-free medium. J Endocrinol (1991) 131:499-506. doi:10.1677/ joe.0.1310499

37. Kraiem Z, Sadeh O, Heinrich R. Preparation and culture of a serum-free human thyroid follicle system and its application for measuring thyroid hormone secretion, iodide uptake and organification, cyclic adenosine monophosphate formation, gene expression, and cell growth. Thyroid (2000) 10:53-7. doi:10.1089/thy.2000.10.53
38. Westermark B, Karlsson FA, Walinder O. Thyrotropin is not a growth factor for human thyroid cells in culture. Proc Natl Acad Sci U S A (1979) 76:2022-6. doi:10.1073/pnas.76.4.2022

39. Roger PP, Baptist M, Dumont JE. A mechanism generating heterogeneity in thyroid epithelial cells: suppression of the thyrotropin/cAMP-dependent mitogenic pathway after cell division induced by cAMP-independent factors. J Cell Biol (1992) 117:383-93. doi:10.1083/jcb.117.2.383

40. Rocha AS, Paternot S, Coulonval K, Dumont JE, Soares P, Roger PP. Cyclic AMP inhibits the proliferation of thyroid carcinoma cell lines through regulation of CDK4 phosphorylation. Mol Biol Cell (2008) 19:4814-25. doi:10.1091/ mbc.E08-06-0617

41. Biondi B, Filetti S, Schlumberger M. Thyroid hormone therapy: a reassessment. Nat Clin Pract Endocrinol Metab (2005) 1:32-40. doi:10.1038/ncpendmet0020

Conflict of Interest Statement: The authors declare that the research was conducted in the absence of any commercial or financial relationships that could be construed as a potential conflict of interest.

Copyright (C) 2017 Kyrilli, Paternot, Miot, Corvilain, Vassart, Roger and Dumont. This is an open-access article distributed under the terms of the Creative Commons Attribution License (CC BY). The use, distribution or reproduction in other forums is permitted, provided the original author(s) or licensor are credited and that the original publication in this journal is cited, in accordance with accepted academic practice. No use, distribution or reproduction is permitted which does not comply with these terms. 